\title{
KOTA PROBOLINGGO: DARI PANOPTIKON KE FRAGMENTED POWER
}

\author{
Anas Hidayat ${ }^{1}$, Y.A. Widriyakara ${ }^{2}$ \\ 1,2. Program Studi Arsitektur, Universitas Katolik Darma Cendika, \\ Jl. Dr. Ir. H. Soekarno No. 201, Surabaya \\ Email: anashiday@yahoo.co.uk
}

\begin{abstract}
Abstrak
Kota Probolinggo yang dirancang pada masa pemerintahan kolonial Belanda, sangat jelas menunjukkan pola kota sebagai sebuah panoptikon berskala kota, seperti teori dari Jeremy Bentham. Di mana kantor residen (pemimpin wilayah) menjadi pusat (juga sekaligus pengawas) dari lingkungan pemerintahan yang linier dan lurus dari selatan (Jalan Raya Pos) ke utara (pelabuhan Probolinggo Lama). Kantor residen Probolinggo ini, secara spasial bisa "mengawasi" area di sebelah utaranya, mulai dari alun-alun, lalu stasiun kereta api yang berada di utara alunalun, lalu benteng-gudang di sebelah utara stasiun kereta api hingga berakhir ke pelabuhan yang berada di Selat Madura. Kekuatan panoptikon ini bukan hanya soal ruang politik saja, tetapi juga termasuk di dalamnya sebagai ruang pertahanan, ruang ekonomi, ruang sosial dan bahkan ruang budaya. Jika dibandingkan dengan kondisi sekarang, maka sekarang ini kekuatan (power) telah berubah polanya dari yang terpusat menjadi lebih terpecah-terpecah, seperti pemahaman dari Richard Rorty tentang pecahnya cermin besar alam raya. Sudah tidak ada lagi pusat yang dominan (dan sekaligus mengawasi), semua memiliki kekuatan sendiri-sendiri untuk menunjukkan diri. Yang menjadi pusat pemerintahan saat ini adalah kantor walikota Probolinggo yang posisi atau letaknya sudah bergeser dari kantor residen lama (sekarang jadi markas Kodim 0820) ke arah barat. Kawasan alun-alun pun kemudian hanya menjadi area simbolis belaka. Stasiun KA berubah menjadi alat transportasi terutama untuk manusia saja, sudah tidak menjadi pengangkut komoditi internasional yang semasif dulu, hubungannya dengan pelabuhan juga telah terputus. Kelemahannya, antar elemen kota menjadi seperti tidak terhubung, tidak ada sinergi antara satu dengan yang lainnya.
\end{abstract}

Kata kunci: Probolinggo, power, panoptikon, cermin pecah.

\begin{abstract}
Title: The City of Probolinggo: From Panopticon to Fragmented Power

The City of Probolinggo, was designed during the Dutch colonial administration. It is very clearly shows the pattern of the city as a city-scale panopticon, as it is mentioned in the theory of Jeremy Bentham. The city layout could be explained as follow: the resident's office (regional leader) becomes the center (as well as the supervisor) of a linear and straight government environment from the south (Jalan Raya Pos) to the north (Probolinggo Lama port). The Probolinggo resident office can spatially "over look" the area to the direction of north, starting from the square, then train station, then the warehouses until it ends at the port located in the Madura Strait. The power of the panopticon is not just a matter of political space, but also includes it as a defense space, economic space, social space and even cultural space. When compared with current conditions, so now the power has changed the pattern from the centralized to more fragmented, as Richard Rorty's understanding of 'the breaking of the great mirror of the universe'.There is no longer a dominant center (and at the same time overseeing), all have their own strength to show themselves. Central to the current administration is the office of the mayor of Probolinggo, whose position has shifted from the old resident's office (now the Kodim 0820 headquarters) to the west. The area of the square was then only a mere symbolic area. The train station has turned into a means of transportation, especially for humans, it is no longer a semi-passive international
\end{abstract}


commodity transporter, its relationship with the port has also been severed. The weakness, between the elements of the city to be like not connected, there is no synergy between one another.

Keywords: Probolinggo, power, panopticon, broken mirror.

\section{Pendahuluan}

Menurut sejarahnya, di era kolonial Belanda, Kota Probolinggo merupakan sebuah kota pesisir di Jawa Timur yang memiliki posisi yang sangat strategis bagi Belanda, karena menghadap ke Selat Madura. Lalu kota ini mulai dirancang dengan sistem "grid" (kotak-kotak) dan menjadi kota perdagangan yang cukup penting, meskipun di masa lalu (di jaman prakolonial), Probolinggo relatif masih kurang dikenal jika dibanding dengan kota-kota lain seperti Gresik, Tuban atau Surabaya yang merupakan bandar-bandar perdagangan besar yang menjadi tempat lalu-lalang kapal-kapal dari berbagai negeri.

Kota Probolinggo yang awalnya dibentuk pada masa kolonial Belanda ini kemudian terus tumbuh dan berkembang menjadi kota yang cukup besar saat ini di masa Indonesia merdeka. Dalam kurun waktu tersebut (sejak kolonial sampai era milenial sekarang) tentunya ada perubahanperubahan yang terjadi dan juga ada beberapa jejak-jejak historisarsitektural yang masih ada dan bisa ditemui. Dari jejak-jejak itulah, kajian ini ingin mencoba untuk mengamati sisi lain dari perkembangan Kota Probolinggo, yakni dari kacamata poskolonial.

Ketika masa kolonial Belanda, era yang cukup berpengaruh terhadap perkembangan Kota Probolinggo adalah Jaman Tanam Paksa atau Cultuurstelsel yang terjadi pada kurun waktu 1830-1870 dan kemudian adanya pembangunan rel Kereta Api antara tahun 1880-1900 yang makin mengukuhkan arti penting Kota Probolinggo di antara kota-kota lainnya.

Dengan adanya Politik Tanam Paksa atau Cultuurstelsel, maka Belanda mulai mengembangkan lahan-lahan pertanian dan juga perkebunan di Probolinggo dan sekitarnya, termasuk di wilayah-wilayah Pasuruan, Lumajang, Jember, Bondowoso dan Situbondo. Dengan komoditas perdagangan unggulan yang dihasilkan antara lain: gula, tembakau dan kopi. Selanjutnya, pembangunan rel kereta api sebagai sarana transportasi dan juga untuk pengangkutan hasil bumi dari sekitar Probolinggo untuk kemudian dikapalkan ke Belanda (Eropa).

Prosesnya, dari kawasan perkebunan yang ada di bagian timur Jawa, hasil bumi diangkut dengan kendaraan lain menuju ke stasiun terdekat, untuk kemudian dibawa menuju stasiun Probolinggo. Di stasiun Probolinggo, komoditas itu kemudian dibongkar dan dimasukkan ke gudang-gudang yang sudah disiapkan Belanda. Gudanggudang ini menjadi sebuah area yang dijaga dengan ketat dan oleh warga sekitar disebut sebagai benteng. Jika komoditas sudah terkumpul dalam jumlah yang diinginkan, kemudian diangkut menuju ke pelabuhan, untuk selanjutnya dimuat dalam kapal-kapal besar dengan berbagai tujuan ke berbagai belahan dunia, terutama untuk pasar Eropa dan sekitarnya. 
Ada beberapa perkembangan yang bisa diamati secara lebih mendalam di sini, terutama dalam kaitannya dengan pembacaan poskolonial. Di sini, kota Probolinggo dirunut secara historis, ketika pada awalnya merupakan kota kolonial yang sangat kental nuansa panoptikon (seperti sebuah "penjara" besar yang terawasi terus-menerus), dengan kantor residen sebagai pusat pengawasnya. Kemudian saat ini, di era reformasi ketika demokrasi sudah dikembalikan kepada rakyat lagi, terjadi sebuah kebebasan ruang yang membuat kekuatan seperti terpecahpecah dan tidak tunggal lagi seperti di masa-masa sebelumnya.
1810

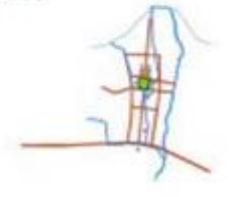

1882

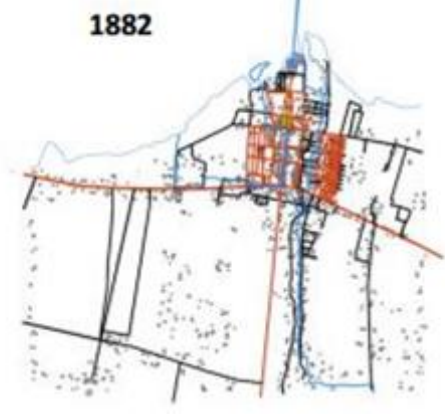

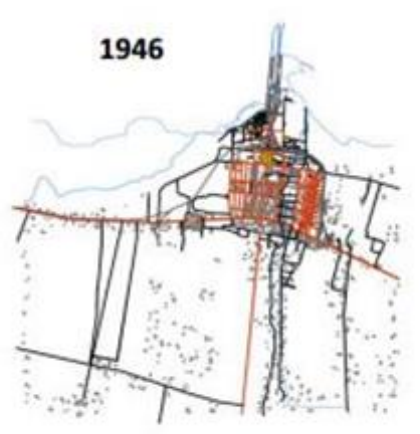

Probolinggo urban evolution

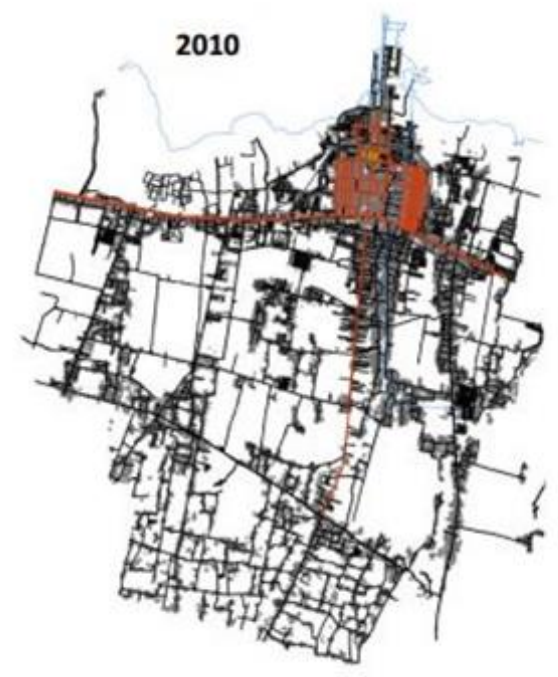

Gambar 1. Perkembangan Kota Probolinggo sejak era kolonial sampai sekarang Sumber: Khoir, 2016

Jika melihat pada peta perkembangan fisik kota Probolinggo pada rentang masa 200 tahun sejak tahun 1810 hingga 2010, terlihat bahwa kota Probolinggo sangat berkaitan dengan pembangunan Groote Postweg atau Jalan Raya Pos yang dibangun oleh Daendels antara Anyer hingga Panarukan sejauh sekitar seribu kilometer. Dari ruas Jalan Raya Pos inilah kemudian kota Probolinggo berkembang.

Di era-era awal sekitar tahun 1810 ini, Kota Probolinggo hanya terdiri dari beberapa ruas jalan antara Jalan Raya Pos dan Pelabuhan yang terletak di ujung utara. Bisa dikatakan masa ini 
masih berupa bakal kota. Pada era berikutnya, di tahun 1882 terlihat bagaimana ruang besar antara Jalan Raya Pos dan Pelabuhan Probolinggo semakin ramai oleh permukiman dan bangunan dengan sistem grid (kotakkotak). Sampai tahun 1946, kondisi tersebut tidak banyak berubah. Baru kemudian berubah secara drastis sampai abad ke 21, tepatnya tahun 2010, Kota Probolinggo sudah berkembang dengan luas beberapa kali lipat dari sebelumnya.

\section{Metode Kontrapuntal}

Pembacaan kontrapuntal adalah cara "membaca" yang ditawarkan oleh Edward Said, seorang tokoh asal Palestina yang melawan "orientalisme" (bagaimana Barat melihat Timur) dengan membuat tandingan yang disebutnya "occidentalisme" (bagaimana Timur melihat Barat). Said membuat sebuah pembacaan tandingan yang terbalik, agar objek yang selama ini terpinggirkan bisa berubah menjadi sebuah subjek baru yang bisa mengambil-alih kekuasaan pembacaan (yang selama ini dikuasai oleh Barat).

Pembacaan model ini merupakan cara membaca dengan cara yang "tak biasa", yaitu dengan cara membawa tema dari luar untuk dibawa masuk ke dalam dan menciptakan interplay. Dengan demikian, pembacaan menjadi lebih hidup, tidak lagi tergantung dengan pola baca lama yang kaku dan cenderung kolot, dan bahkan tidak memunculkan hal baru yang lebih kreatif. Pembacaan kontrapuntal seperti ini diharapkan dapat memberikan cara pandang yang lebih kreatif dalam melihat perkembangan dan fenomena di sebuah kota, termasuk dalam kasus ini adalah Kota Probolinggo.

\section{Dari Kolonial ke Era Suharto: Panoptikon}

Jeremy Bentham, seorang filsuf asal Inggris, merancang sebuah penjara imajiner yang disebutnya sebagai panoptikon atau panopticon (BrunonErnst, 2012), ini merupakan penjara khusus dengan konsep yang tidak biasa. Di penjara ini, narapidana sangat diawasi dengan ketat di dalam ruangruang dengan konfigurasi setengah lingkaran. Pengawasannya antara lain dengan lampu sorot yang sangat terang, yang diarahkan kepada mereka (dan ke ruang-ruang mereka), sehingga mereka terus-menerus merasa diawasi.

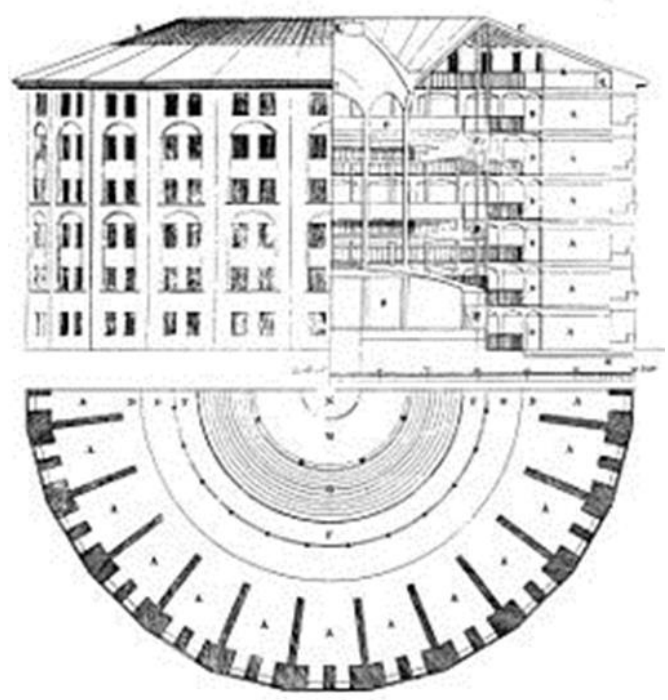

Gambar 2. Penjara panoptikon menurut Jeremy Bentham, digambar oleh Willey Reveley tahun 1791

Sumber: wikipedia.org, diunduh November 2018

Begitu terangnya lampu sorot itu, mereka sangat silau dan tentu saja mata mereka seperti dibutakan dan tidak bisa melihat sekitarnya, termasuk juga tak bisa melihat penjaga yang mengawasi mereka. Bahkan, jika penjaga itu meninggalkan tempat 
mereka, para napi yang tersorot lampu terang-benderang itu tidak akan tahu dan masih terus merasa diawasi, siang dan malam.

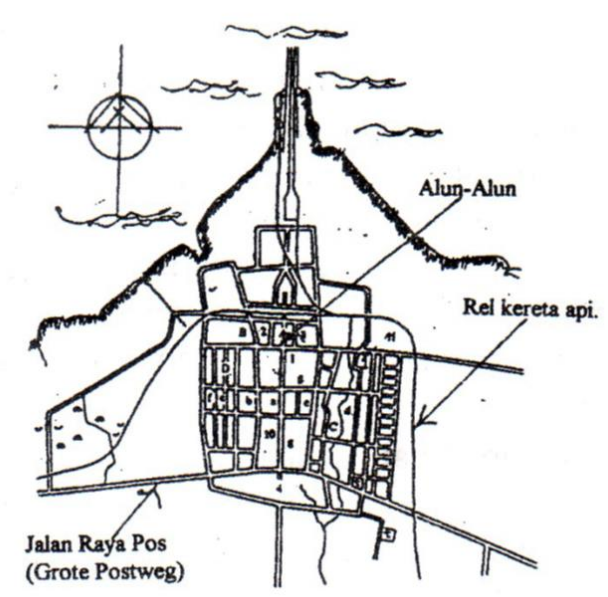

Gambar 3. Peta kawasan Kota Probolinggo, 1880-1940

Sumber: Handinoto, 2012

Pola atau tatanan sebuah kota, bisa sangat mirip dengan konsep penjara panoptikon yang diusulkan Bentham.

Terutama ketika penguasa merasa perlu untuk menjadi pengawas bagi warga kotanya dan segala kegiatan yang terjadi di dalamnya. Memang, sebuah kota bisa ditinjau dari perspektif power atau kekuasaan (Kusno, 2006).

Kota Probolinggo sepenuhnya dikuasai Belanda pada tahun 1743 (Handinoto, 2010). Probolinggo pada masa kolonial ini memang seperti penjara panoptikon. Ada "sang penjaga" yang berada di ujung selatan (di ruas Jalan Raya Pos), yaitu Kantor Residen yang mengawasi segala kegiatan yang dilakukan oleh warga di kota Probolinggo, bahkan kawasan Alunalun dan Pendapa Kabupaten Probolinggo pun berada dalam pengawasan dari kantor Residen. Panoptikon ini membujur dari selatan ke utara, dari Kantor Residen sampai ke Pelabuhan Lama Probolinggo yang membentuk sumbu berupa garis lurus yang cukup "rapi".

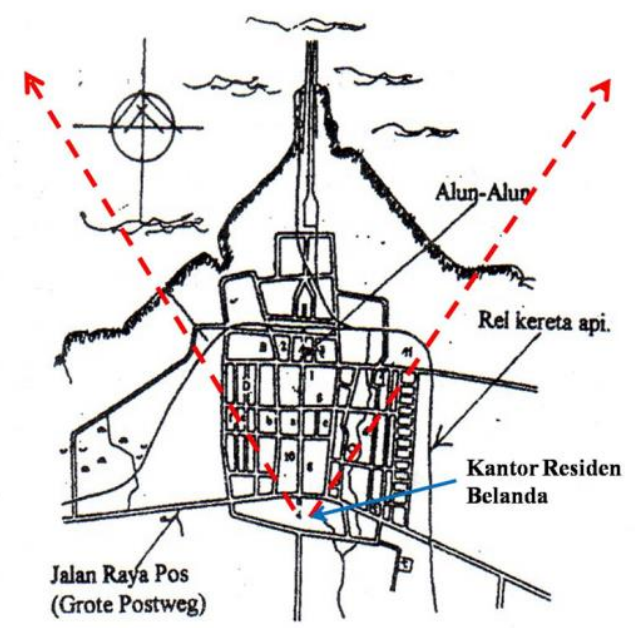

Gambar 4. Peta Kota Probolinggo sebagai panoptikon (era kolonial)

Sumber: Handinoto, 2012 dengan tambahan notasi

Lalu, pada masa pasca kemerdekaan, di era kekuasaan Presiden Sukarno (Orde Lama) dan Presiden Suharto (masa Orde Baru), Kota Probolinggo juga masih bisa disebut sebagai sebuah kota Panoptikon, seperti yang diimajinasikan oleh filsuf Inggris bernama Jeremy Bentham. Meskipun di era Presiden Sukarno dan Suharto sudah memasuki era merdeka (lepas dari penjajahan), tetapi pola panoptikon masih sangat terlihat. Terutama pada masa Presiden Suharto yang represif, panoptikon era kolonial sepertinya masih dilanjutkan keberadaannya. Apalagi ketika kantor Residen Belanda kemudian diubah fungsinya menjadi Markas Kodim 0820 yang memposisikan militer sebagai pengawas dan penjaga, makin kuatlah konsep panoptikon tersebut. 


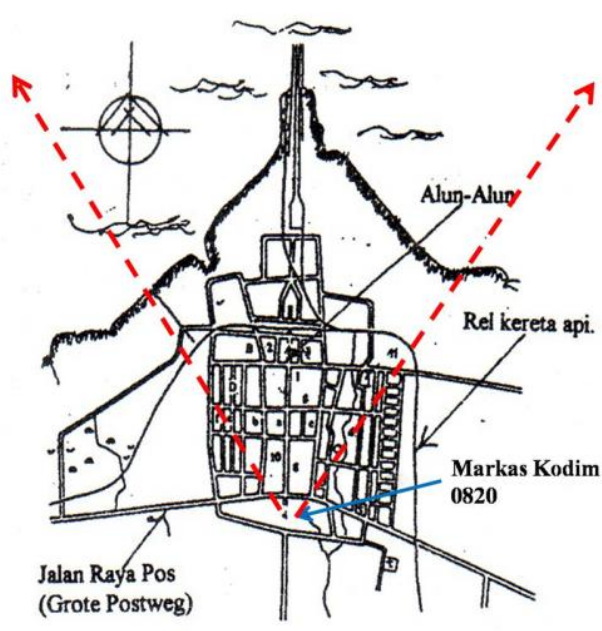

Gambar 5. Peta Kota Probolinggo sebagai panoptikon (era kemerdekaan)

Sumber: Handinoto, 2012 dengan tambahan notasi

Jadi, ketika Indonesia sudah merdeka, kondisi panoptikon ini bisa dikatakan tidak banyak berubah, hanya beralih era kekuasaan saja. Era Sukarno dan Suharto bisa dikatakan masih menjadi kelajutan dari panoptikon itu. Meskipun panoptikonnya tidak seketat dan sekuat seperti masa kolonial, tetapi kekuatannya masih bisa dirasakan oleh masyarakat secara real pada masa itu. Markas Kodim 0820 menjadi jejak bagaimana militer menjadi pengawas yang ditakuti di era Orde Baru dan menjadi pusat penjaga panoptikon.

\section{Era Reformasi: Pecahnya Mirror of Nature}

Ketika memasuki era reformasi, terjadi banyak perubahan yang mengubah pola-pola kekuatan yang ada di Kota Probolinggo. Antara lain masuknya fungsi-fungsi yang lain (dan baru) ke alun-alun kota Probolinggo. Juga bergesernya pusat pemerintahan dari militer ke sipil (sebelumnya dari residen ke walikota), sehingga pola panoptikon menjadi terkikis dan sedikit demi sedikit berubah. Ditambah lagi dengan sudah semakin tuanya gudang dan benteng yang berada di utara stasiun kereta api, sehingga jejaknya semakin tidak terawat lagi. Stasiun pun hanya dipakai untuk transportasi manusia dan barang antar kota, namun tidak ada lagi angkutan komoditas yang seperti dulu ketika masa kolonial di mana komoditas diangkut dari dan ke pelabuhan Probolinggo.

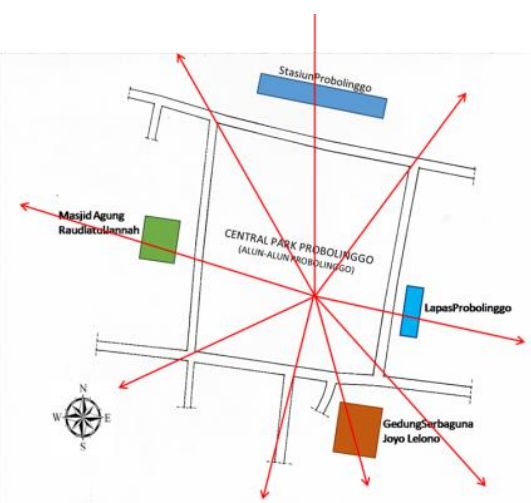

Gambar 6. Peta alun-alun Probolinggo saat ini, kekuatan yang terfragmentasi Sumber: Penelitian, 2018

Yang terjadi kemudian adalah munculnya fragmented powers, kekuatan-kekuatan yang saling terpecah-pecah, saling bersilang satu sama lain. Seperti dinyatakan oleh Richard Rorty sebagai pecahnya cermin besar alam raya (mirror of nature). Jika kekuatan yag terpecahpecah ini bisa dikelola dengan baik dan terkoordinasi satu sama lain, akan menjadi sebuah kekuatan yang simultan dan saling mendukung. Tetapi jika tanpa irama yang jelas, justru akan saling mendegradasi dan saling berlawanan satu sama lain. Misalnya saja kawasan Alun-alun yang dulu berada dalam pengawasan panoptikon, sekarang menjadi lepas dan menjadi sebuah kawasan yang terpecah-pecah, ada kekuatan ekonomi, ada kekuatan politik dan lain sebagainya yang membuat alun-alun menjadi kawasan 
yang "bebas" dan tak hanya berada di bawah kendali satu pihak. Ada banyak pihak yang saling tarik-menarik kekuasaan di sini.

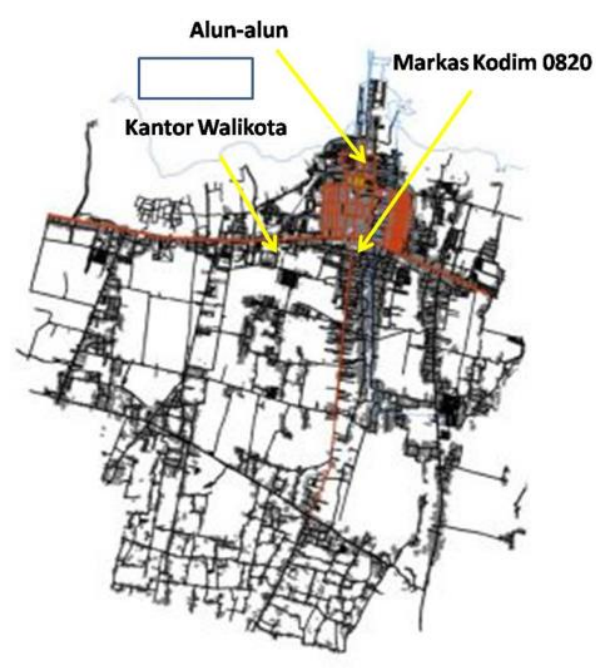

Gambar 7. Peta alun-alun Probolinggo saat ini, kekuatan yang terfragmentasi Sumber: Khoir, 2016

Pecahnya cermin besar alam raya ini juga menunjukkan bahwa ada banyak kekuatan yang memiliki posisi sama, tanpa dominasi dan tanpa hegemoni yang besar. Dengan demikian, ini sebetulnya sebagai sebuah potensi untuk membuat sebuah sistem ruang yang lebih egaliter di kota Probolinggo dan tidak memaksa atau arogan dalam menentukan otoritas. Intinya adalah dialog antar berbagai kekuatan yang ada, sehingga bisa saling memahami dan saling mendukung satu sama lain.

Yang terjadi saat ini yaitu antar kekuatan yang ada tidak saling mendukung atau saling mengisi satu sama lain, tetapi lebih sering berjalan sendiri-sendiri. Maka tidak ada sinergi, tidak ada kordinasi yang bisa menyatukan semua kekuatan komponen tersebut dalam satu irama. Padahal ini adalah sesuatu yang sangat potensial untuk digarap demi kemajuan dan perkembangan Kota Probolinggo.

\section{Kesimpulan}

Pada dasarnya panoptikon itu memang tidak manusiawi, bersifat hegemonik dan mendominasi. Akan tetapi, sistem panoptikon ada benarnya juga dilihat dari pandangan yang mengutamakan disiplin, dengan sebuah irama yang sama atau senada. Sistem ini memang kurang bagus, tetapi ada sisi baiknya juga, yakni dari sudut pandang pemerintah yang menginginkan semua terawasi, rapi dan menurut pada satu komando yang sama.

Pada akhirnya, fragmentasi atau pemecahan kekuatan di Kota Probolinggo ini bisa didialektikkan dengan panoptikon, dalam arti mengambil sebuah posisi paradoksal, setengah panoptikon dan setengah cermin pecah. Dengan begitu, maka kekuatan yang terpecah masih punya kesempatan untuk didialogkan kembali, untuk disinergikan kembali, sehingga jejak-jejak masa lalu (jejak budaya, jejak sejarah, jejak ekonomi, jejak sosial dan lain-lain) masih bisa ditemukan dan dirunut sejarahnya.

Jadi, di sini ada perimbangan tarikmenarik antara kekuatan sentrifugal yang menuju ke pemecahan kekuatan dan kekuatan sentripetal yang menuju ke satu pusat di tengah. Dengan perimbangan ini, akan ada dialog yang lebih intens antara kekuatan-kekuatan yang ada di kota, baik dari segi pemerintahan, kultural, spiritual, ekonomi, kekuatan informal dan nonformal dan lain sebagainya. Semua kekuatan itu memiliki hak untuk bersuara di dalam menentukan Kota Probolinggo ke depan. 
Mungkin ini memang bukan hal yang mudah, tetapi melihat dari perkembangan yang semakin bagus, maka bukan tidak mungkin terjadi dialog-dialog yang lebih membangun dari fragmentasi kekuatan (dan sekaligus fragmentasi ruang) yang ada di Kota Probolinggo.

\section{Daftar Pustaka}

Brunon-Ernst, Anne (Ed.). (2012). Beyond Foucault: New perspectives on Bentham's panopticon. Farnham, UK: Ashgate Publishing.

Handinoto. (2010). Arsitektur dan kota-kota di Jawa pada masa kolonial. Yogyakarta: Graha Ilmu.

Handinoto. (2012). Sejarah kota Probolinggo $1746-1940$. Probolinggo: Museum Probolinggo; Dinas Pemuda Olahraga Budaya dan Pariwisata Kota Probolinggo.

Khoir, Abduh. (2016). Menilik bangunan-bangunan kuno di Probolinggo. Diunduh 12 November 2018, dari https://www.goodnewsfromindo nesia.id/2016/07/25/kota-kamidibangun-oleh-kolonialisbelanda

Kusno, Abidin. (2006). Di balik pascakolonial: Arsitektur, ruang kota dan budaya politik di Indonesia. Surabaya: Airlangga University Press. 